A Semmelweis Egyetem, Általános Orvostudományi Kar, Ortopédiai Klinika közleménye

\title{
A 8-as lemezes temporer hemiepiphyseodesis technikával elért eredményeink csontdysplasiák és csontanyagcsere-zavarok okozta gyermekkori térd körüli tengelydeformitások kezelésében
}

\author{
DR. HORVÁTH NIKOLETTA, DR. KISS SÁNDOR, DR. TEREBESSY TAMÁS, \\ DR. DOMOS GYULA, SZEKERES ESZTER o. h., DR. SZÖKE GYÖRGY
}

Érkezett: 2014. december 19.

DOI: 10.21755/MTO.2015.058.0203.002

\section{ÖSSZEFOGLALÁS}

A térd körüli gyermekkori tengelydeformitásoknak a növekedés szabályozásával történő korrekciójára eleinte használt ácskapcsot, transphysealis csavart, fokozatosan felváltotta a kevésbé rigid rögzítést biztosító 8-as lemez. A Semmelweis Egyetem Ortopédiai Klinikájának Gyermekosztályán 2006 óta használjuk a 8-as lemezt a physis aktivitásának átmeneti gátlására a különböző eredetű térdkörüli tengelydeformitás, valamint végtaghossz-különbség korrekciója céljából. 82 betegnél ültettünk be 8 -as lemezt. Munkánk során annak a 16 betegnek az eredményeit dolgoztuk fel, akiknél csontrendszer-betegség állt a tengelyeltérés hátterében. Az összes mérésben szereplő mechanikai tengely által bezárt szög változása (korrekció) átlagosan $12,4^{\circ}(2-33)$ volt. A betegek nagyobb részénél a femur distalis részén észleltük a korrigálandó deformitást. Mind a femur distalis, mind a tibia proximalis részén jelentős javulást értünk el. Tapasztalataink szerint a 8-as lemezes temporaer epiphyseodesis által elért irányított növekedés segítségével nemcsak idiopathiás, hanem csontdysplasiák és csontanyagcsere-betegségek okozta tengelydeformitások is jól kezelhetők.

\section{Kulcsszavak: $\quad$ Csontanyagcsere-zavar; Csontdysplasia; Epiphysis; Gyermekkor; Lemezes rögzítés; Rachitis; Térdízületi deformitás;}

N. Horváth, S. Kiss, T. Terebessy, Gy. Domos, E. Szekeres, Gy. Szöke: Clinical results of temporary hemiepiphyseodesis performed with eight-plate in the treatment of pediatric axial deformities around the knee caused by bone dysplasia and metabolic disorder

Staples and trans-epiphyseal screws used initially for controlled growth correction for paediatric axial deformities around the knee were gradually replaced by the eight-plate, which provides less rigid fixation. We use the eight-plate at the Paediatric Department of Semmelweis University Orthopaedic Clinic since 2006 for temporary inhibition of epiphyseal activity in case of axial deformities around the knee of diverse origins and for correction of limb length differences. We implanted an eight-plate in case of 82 patients. We analysed the results of 16 patients with systemic bone disease causing axial deformity. Change of the angles between all measured axes (correction) was $12.4^{\circ}$ on the average $\left(2-33^{\circ}\right)$. Deformity requiring correction was present on the distal femur in the majority of the cases. We could achieve considerable improvement both on the distal femur and proximal tibia. Based on our experience, not only idiopathic, but also axial deformities caused by dysplasia and metabolic bone diseases can be successfully treated with an eight-plate providing growth control by temporary epiphyseodesis.

Keywords: $\quad$ Bone diseases, developmental - Surgery;

Bone diseases, metabolic - Surgery; Bone plates; Child;

Epiphyses - Surgery; Knee Joint - Abnormalities/Surgery;

Rickets - Surgery; 


\section{BEVEZETÉS}

Az ortopédia egyik klasszikus problémája a gyermekkori térd körüli tengelydeformitás kezelése. A kisgyermekkorban, a járástanulás időszakában észlelt genu varum, valamint a 4 éves kor körüli valgus deformitások általában spontán korrigálódnak (12). Ezek mellett gyakran látunk kóros mértékú, de idiopathiásnak mondható deformitásokat, amelyek kezelést igényelnek. A legnagyobb odafigyelést és a kezelés tervezését mégis a ritkább, anyagcsere- és csontrendszerbetegségek talaján kialakult térd körüli tengelydeformitások igénylik.

\section{Történelmi áttekintés}

A múlt század közepéig az egyetlen megoldási lehetőségként a különböző osteotomiákat használták. 1933-ban Phemister közölte módszerét, amely a növekedési porcok végleges lezárásával célozta a végtaghossz-különbségek, illetve tengelyeltérések korrekcióját (11). Az 1949ben Blount által ismertetett, ácskapoccsal végzett epiphyseodesis a növekedési porc roncsolása nélkül, kisebb beavatkozással, rövidebb kórházi tartózkodással, gipszrögzítés és tehermentesítés nélkül tette lehetővé, hogy tengelykorrekciót végezzünk (2). Ez oly módon történik, hogy a növekedési porcok aktivitását csak az egyik oldalon (lateralisan vagy medialisan) gátoljuk átmenetileg, így a csontok növekedésének irányításával („guided growth") hónapok-évek alatt érjük el a kívánt korrekciót. 1984-ben Bowen ismertette a percutaneous drilling módszerét. Ennek során képerősítő kontrollja alatt károsítják a növekedési porcot fúró segítségével $(1,4)$. 1998-ban Métaizeau a transphysealis csavarozás (PETS, percutaneous transphyseal screws) módszerét ismertette (9). 2006-ban Novais 10 hypophosphataemiás rachitises beteg ácskapoccsal végzett korrekciós eredményeiről számolt be. Közleményükben már megemlítik, hogy kétlyukú lemez használata is lehetséges, amely fiatalabb betegeknél is használható lenne, és kevesebb szövődménnyel járna (10). A irodalmi áttekintésben említett irányított növekedést létrehozó módszerek közül Phemister módszere és a percutan drilling véglegesen lezárják a fúgákat. Az ácskapocs, valamint a transphysealis csavarozás pedig számos bizonytalansági faktort tartalmaz. A transphysealis csavarozásnál a csavarnak a növekedési porc aktivitására kifejtett hatása bizonytalan és kiszámíthatatlan. A közlemények beszámolnak olyan esetekről, ahol egy-egy csavar a physis teljes lezáródását okozta, más esetben alig, vagy egyáltalán nem okczout növekiedésgátlást. Így a tengelykorrekció nehezen tervezhető. $\mathrm{Az}$ ácskapoccsal sikeresen lehet az alsó végtagi tengelyeket korrigálni, ugyanakkor rigid volta miatt gyakran kimozdul, eltörik, emellett a hatására létrejövő direkt, hirtelen kompresszió, valamint a beültetésekor okozott trauma nagyobb arányban okozza a physis károsodását, idő előtti lezáródását.

\section{ANYAG ÉS MÓDSZER}

A Semmelweis Egyetem Ortopédiai Klinikájának Gyermekosztályán 2006 óta 82 betegnél ültettünk be 8 -as lemezt. Munkánk során annak a 16 betegnek az eredményeit dolgoztuk fel, akiknél csontrendszerbetegség, illetve csontanyagcsere zavar állt a térdkörüli tengelyeltérés hátterében. Ezek közül a leggyakoribb, deformitást okozó csontdysplasia az exostosis cartilaginea multiplex volt ( 8 beteg), a csontanyagcsere zavarok közül pedig kiemelhetjük a D-vitamin rezisztens rachitist (4 beteg). Két betegünknél renalis osteodystrophia, és egy-egy betegnél spondyloepiphysealis dysplasia és enchondromatosis volt az alapbetegség.

\section{Mütéti technika}

2-3 cm-es metszésből képerősítő kontrollja mellett a femur distalis és/vagy tibia proximalis növekedési porcait egy-egy kétlyukú lemezzel (1. ábra) és 2-2 csavarral hidaljuk át oly módon, hogy a feltárás során a periosteum és a perichondrium integritását megőrizzük, tehát a lemez a periosteumra fekszik fel. A lemezt úgy kell pozícionálni, hogy az pontosan lateralisan vagy medialisan a középvonalban helyezkedjen el, ezáltal kerülhetjük el a nem kívánt sagittalis irányú deformitások kialakulását. A csavarok behelyezése során ügyelni kell arra, hogy ne sértsük a növekedési 
porcot, illetve a csavar hosszúságának helyes megválasztása is fontos az effektivitás szempontjából. Posztoperatív rögzítésre nincs szükség, a mútét másnapján a beteget operált végtagjainak teljes terhelése mellett, segédeszköz nélkül mobilizáljuk, és igyekszünk a térd mútét előtti mozgástartományát minél hamarabb elérni.

12 betegnél a femur distalis részén végeztünk epiphyseodesist, ezek közül 6 volt kétoldali beavatkozás. 8 betegnél a tibia proximalis részén végeztük az epiphyseodesist, itt 2 esetben történt kétoldali mútét. 4 betegünknél mind a femur distalis, mind a tibia proximalis részének növekedési porcát gátoltuk, egy esetben mindkét oldalon. A 16 beteg 23 térdén végeztünk tengelykorrekciót, összesen $28 \mathrm{db}$ 8-as lemezt ültettünk be.

A deformitás jellege (valgus vagy varus), és annak helye (femur vagy tibia) szerint döntöttük el a desis lokalizációját. Ez utóbbi objektív megítélésében a végtagok mechanikai tengelyei által bezárt szögeket vettük alapul. $\mathrm{Az}$ LDFA (lateralis distalis femoralis szög) normálértéke $80-90^{\circ}$, az MPTA (medialis proximalis tibialis szög) értéke fiziológiás viszonyok közt szintén 85-90. (2. ábra) Ezek gyakorlatilag a csontok mechanikai tengelye és a térdízület síkja által bezárt szögeket jelentik, s az utánkövetés során is ezeket használtuk a korrekció mértékének elemzésére. A rendszeres radiológiai követés során teljes alsó végtagi felvételeket készítettünk terhelés mellett, és a standard mechanikai tengelyeket, szögeket mértük. A betegeket háromhavonta hívtuk vissza kontrollra. Ezáltal a kezelés befejezését is úgy tudtuk időzíteni, hogy a korrekció mértékét, a beteg életkorát,

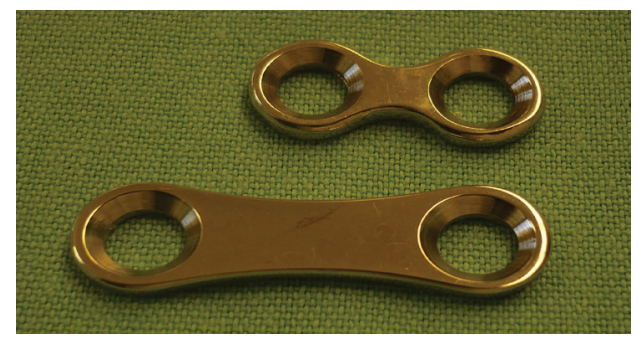

1. ábra A SE Ortopédiai Klinikán temporer epiphyseodesishez használt 8-as lemezek. csontérettségét is figyelembe véve optimális eredményt érjünk el, elkerülve a túlkorrekciót is.

A betegek életkora a 8-as lemez beültetése idején átlagosan 10,9 év volt (4 év - 15 év). Befejezettnek tekintettük azt a 12 esetet, akiknél a fémeket már eltávolítottuk, náluk a kezelés időtartama átlagosan két év volt (12-46 hónap). Egy beteg esetében szintén befejezettnek ¿ekintjük a kazelési, noha a fémet még nem távolítottuk ugyan el, de a növekedési porcok már lezáródtak. Három betegnél a kezelés még folyamatban van, a beültetés óta átlagosan 11,5 hónap (6-17 hónap) telt el.

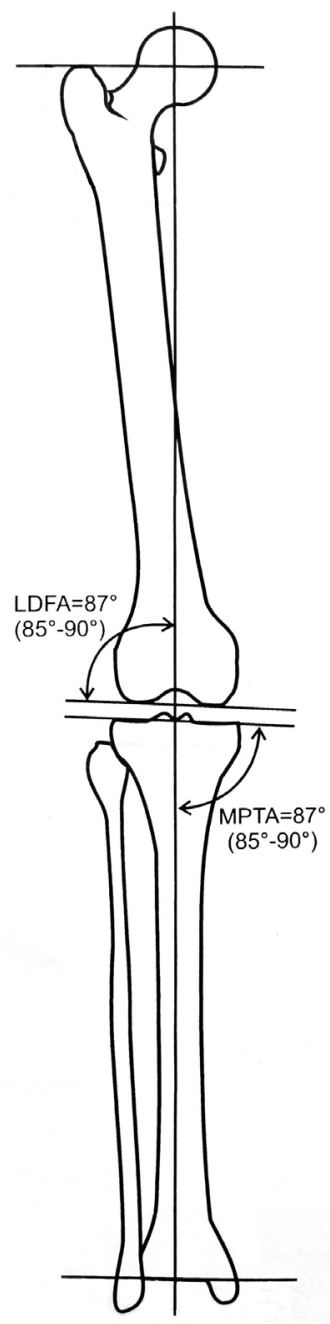

2. ábra Mechanikai tengelyek és a vizsgálat során mért szögek 


\section{EREDMÉNYEK}

Az összes mérésben szereplő mechanikai tengely által bezárt szög változása (korrekció) átlagosan $12,4^{\circ}(2-33)$ volt. $A$ betegek többségénél a femur distalis részén észleltük a korrigálandó deformitást. A lateralis distalis femoralis szögek (LDFA) átlagos változása a jobb oldali (9 eset) beavatkozásoknál $12,1^{\circ}$ $\left(5-24^{\circ}\right)$ volt, a bal oldalon (9 eset) $11,2^{\circ}$ $\left(2-29^{\circ}\right)$. A tibia tengelyének korrekcióját a betegek kisebb hányadában találtuk szükségesnek. A medialis proximalis tibialis szögek (MPTA) a jobb oldalon (4 eset) átlagosan $12,75^{\circ}$-ot $\left(2-33^{\circ}\right)$, a bal oldalon (6 eset) $13,6^{\circ}$-ot $\left(7-26^{\circ}\right)$ változtak. Az egyes gátolt epiphysiseknél észlelt szögváltozásokat táblázatban ábrázoljuk, a cél minden esetben a $85^{\circ}$ és $90^{\circ}$ közötti szögértékek elérése volt (1. táblázat). A 3. ábrán egy hypophosphataemiás rachtises beteg beavatkozás előtti és utáni klinikai képeit és röntgenfelvételeit, a 4. ábrán a spondyloepiphysealis dysplasiás betegünk röntgenfelvételeit mutatjuk be. Szeptikus szövődményt, fémanyag kimozdulást, implantátumtörést nem tapasztaltunk. A lemez direkt hatásaként nem észleiłünk lezáródás: sem a növekedési porcokon. Problémaként merült fel a legfiatalabb betegünknél, hogy az epiphysis egyenetlensége miatt az egyik lemezt nem mertük a megfelelő hosszúságú csavarral rögzíteni. Ennél az epiphysisnél nem történt korrekció, csak a csavar hosszabbra cserélését követően.

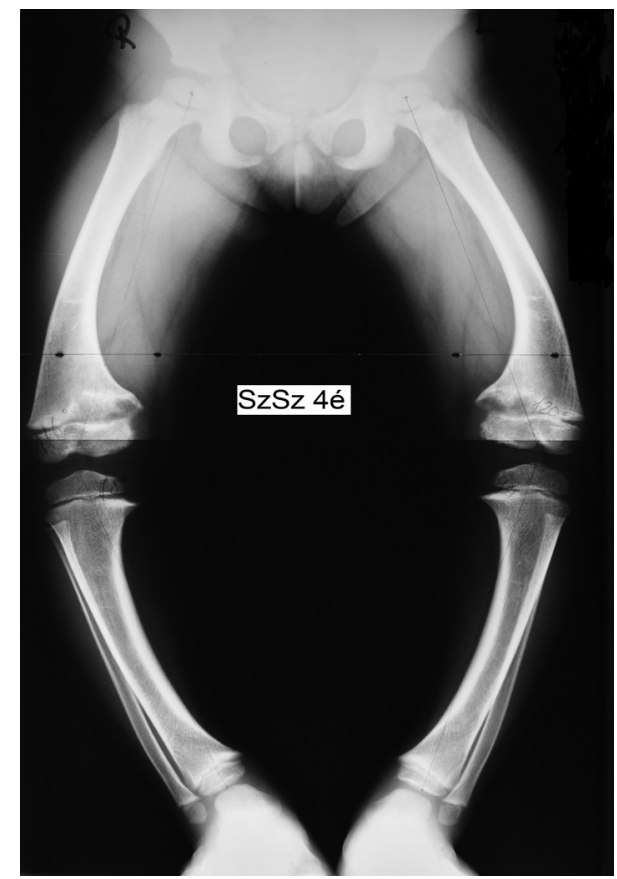

3. ábra Hypophosphataemiás rachitises beteg és röntgenfelvételei a 8-as lemezek beültetése elött, 4 évesen $(a-b)$ 

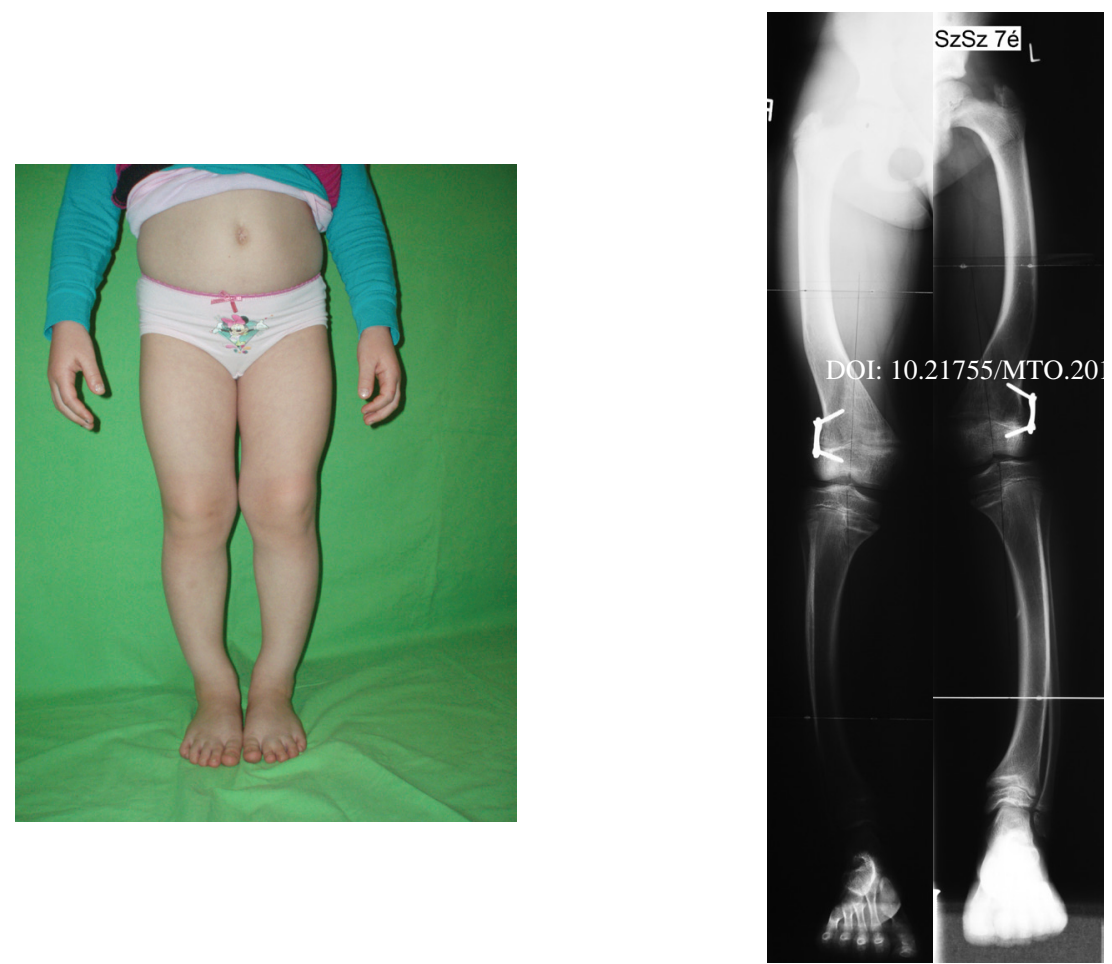

3. ábra A betegröl készült klinikai kép és röntgenfelvételek 3 évvel később (c-d)
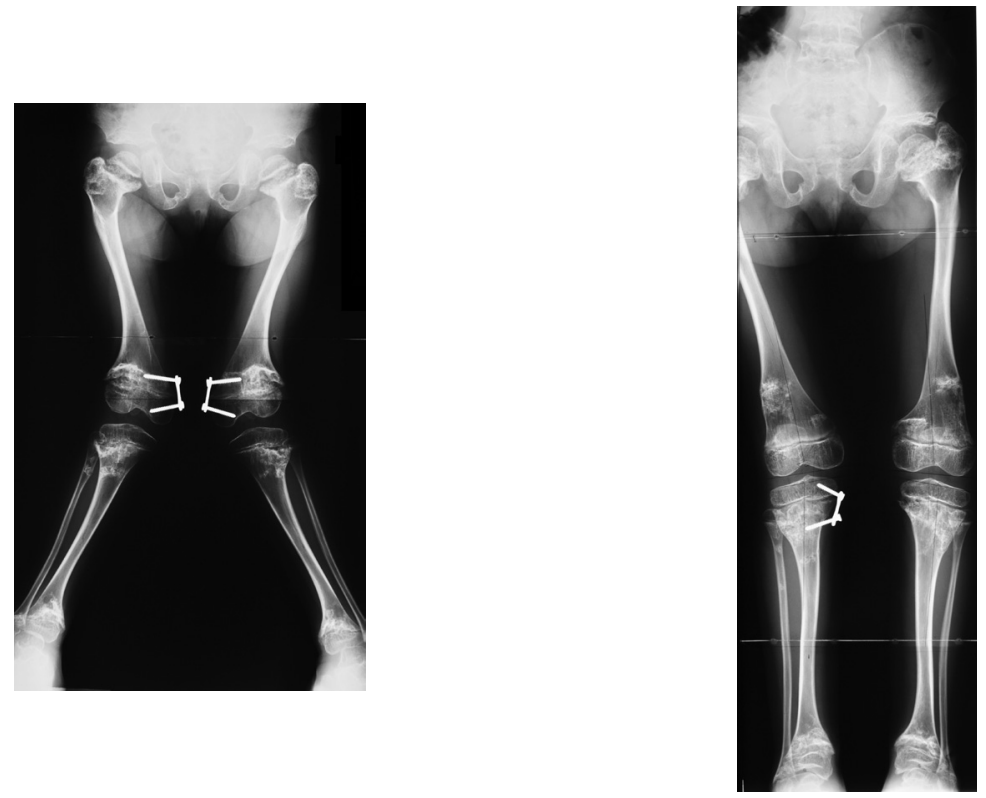

4. ábra Spondyloepiphysealis dysplasiás beteg röntgenfelvételei 5 éves korban a beültetés után közvetlenül (a), majd 7,5 éves korban (b). Idöközben a femurból eltávolitottuk a fémeket, és együlésben újabb temporaer gátlást kezdtünk a jobb tibia proximalis medialis epiphysisén. 
I. táblázat A 8-as lemezzel gátolt egyes physisekhez tartozó szögérték-változások. A betegek nevének kezdöbetűi mellett diagnózisuk rövidítése szerepel.

\begin{tabular}{|c|c|c|c|c|}
\hline Beteg & Jobb femur & Bal femur & Jobb tibia & Bal tibia \\
\hline S. D. (Spondyloepiphysealis dysplasia) & $17^{\circ}$ & $29^{\circ}$ & $2^{\circ}$ & \\
\hline B. K. (FHR) & $24^{\circ}$ & $25^{\circ}$ & & \\
\hline S. S. (FHR) & $8^{\circ}$ & $11^{\circ}$ & & \\
\hline N. $P(R O)$ & $11^{\circ}$ & $2^{\circ}$ & $6^{\circ}$ & $11^{\circ}$ \\
\hline M. E. (ECM) & $10^{\circ}$ & & & \\
\hline P. B. (ECM) & $9^{\circ}$ & & & \\
\hline T. K. (FHR) & $12^{\circ}$ & $2^{\circ}$ & & \\
\hline V. V. (FHR) & $5^{\circ}$ & $10^{\circ}$ & & \\
\hline L. L. (ECM) & $13^{\circ}$ & & & $20^{\circ}$ \\
\hline V. A. (ECM) & & $4^{\circ}$ & & $8^{\circ}$ \\
\hline H. D. (ECM) & & $3^{\circ}$ & & \\
\hline B. Al. (ECM) & & & $10^{\circ}$ & \\
\hline Ö. M. (ECM) & & & $33^{\circ}$ & $26^{\circ}$ \\
\hline B. An. (RO) & & & & $10^{\circ}$ \\
\hline C. V. (Enchondromatosis) & & & & $7^{\circ}$ \\
\hline T. S. (ECM) & & $15^{\circ}$ & & \\
\hline Változás átlaga & $12,1^{\circ}$ & $11,2^{\circ}$ & $12,75^{\circ}$ & $13,6^{\circ}$ \\
\hline \multicolumn{5}{|c|}{$\begin{array}{l}\text { FHR: Familiáris hypophosphataemiás rachitis } \\
\text { RO: Renalis osteodystrophia } \\
\text { ECM: Exostosis cartilaginea multiplex }\end{array}$} \\
\hline
\end{tabular}

\section{MEGBESZÉLÉS}

2007-től, a Stevens módszerével elért eredmények közlését követően az ácskapocs, illetve transphysealis csavar alkalmazása után inkább a 8-as lemezes technika vált használatossá (13). 2008-ban Stevens 14 D-vitamin hiányos, hypophosphataemiás rachitises és renalis osteodystrophiás beteg közül 10 betegnél használt ácskapcsot, 4 betegnél 8-as lemezt. Utóbbiaknál jóval kisebb volt a beültetett fémek kimozdulásának és a deformitás recidivájának aránya. Stevens szerint fontos a korai beavatkozás a kóros növekedés megakadályozására, ezáltal elkerülhetők az osteotomiák, valamint a végtag tengelyének normális felé terelése hemiepiphyseodesissel a növekedési porcok fiziológiás múködését is elősegíti, nem pedig gátolja (14). Szintén 2008-ban Burghardt és munkatársai térd- és bokatáji deformitásokat is kezeltek csavarral és lemezzel, jó eredménnyel (5). Emellett azonban az ácskapcsok sem szorultak ki teljesen a gyakorlatból, Cho 2009-ben 9 multiplex epiphysealis dysplasiás beteg 17 térdének ácskapoccsal történt kezeléséről számolt be. A femuron átlagosan 15,3, a tibián 8,6 fokos változást sikerült elérniük, szövődményt nem tapasztaltak, azonban a recidíva aránya magas volt, 9 esetben észlelték ezt a fémeltávolítás után (7). 2010-ben Burghardt és Herzenberg közöltek 7 esetet, rendszerbetegség talaján kialakult tengelydeformitás miatt 8-as lemezzel végzett irányított növekedésről. Öt betegnél sikerült a tervezett tengelykorrekciót elérni és megőrizni (6). 2011-ben nagyobb beteganyagról számolt be Boero és munkatársai, összesen 58 betegnél végeztek korrekciót 8-as lemezzel. Ezek közül 28 esetben történt a beavatkozás 
dysplasia, illetve anyagcserezavar okozta deformitás miatt, 22 esetben teljes korrekciót, 5 esetben részleges korrekciót sikerült elérni, s csak egy esetben nem sikerült javítani az alsó végtag tengelyén (3). Az irodalom áttekintése alapján egyértelmúnek tünik, hogy a korábban alkalmazott technikák és implantátumok után a 8-as lemez sokkal tervezhetőbb, biztonságosabb, rugalmasabb, ugyanakkor stabilabb és a physiseket kevésbé veszélyeztető, átmeneti növekedésgátlást biztosíthat. A 8-as lemez használatával elért eredményekről az elmúlt években számos cikk jelent meg, azonban kevesen foglalkoztak olyan betegeknél elért eredményekröl, akiknél a tengelydeformitás valamilyen csontanyagcserezavar, illetve dysplasia talaján alakult ki. Jellemző módon hypophosphataemiás rachitisnél varus deformitást, exostosis cartilaginea multiplex esetén valgus tengelyeltérést tapasztalunk.

A Klinikánkon végzett beavatkozások eredményei szerint, valamint az irodalomban megjelent beszámolók alapján az epiphysisek kétlyukú lemezzel történő aszimmetrikus növekedésgátlásával nemcsak idiopathiás térdkörüli

hanem dysplasiáknál, csontanyagcsere betegségeknél kialakult deformitásokat is jól lehet korrigálni. Az ilyen fajta növekedésirányítással elkerülhetők a sokkal nagyobb mútéti megterhelést jelentő osteotomiák, amelyek hosszú gipszrögzítéssel, időszakos tehermentesítéssel kell, hogy járjanak. A módszer értelemszerúen csak aktív növekedési porcok mellett lehet eredményes, a növekedés befejeződése közelében szerényebbek az eredmények. Minél intenzívebb a növekedés, annál gyorsabban történik a korrekció. Azoknál a betegeinknél, akik későn, a physisek lezáródása előtt nem sokkal jelentkeztek Klinikánkon, nem értük el a teljes korrekciót. Ezekben az esetekben számítottunk a korlátozott mértékú javulásra, mégis elvégeztük a mútéteket, kihasználandó azt a kevés „korrekciós potenciált”, ami rendelkezésre állt a lezáródásig. Ezeknek a betegeknek az eredményei nem szerepelnek a vizsgálatban.

A kóros ınüködésúi phiysisek e'setér (mint amilyennel az esetünkben kiválasztott betegcsoportban találkozhatunk) ugyan lassabban érünk el eredményt, mint idiopathiás esetekben, de saját tapasztalatainkra alapozva, valamint figyelembe véve a nemzetközi irodalomban megjelent közleményeket, nyitott physisek mellett ez az elsődlegesen ajánlható korrekciós módszer. A végtag tengelyének normális felé terelése a növekedési porcok fiziológiás működését is elősegíti. Ezért nagyon fontos a beavatkozás időpontjának alapos megtervezése, és a kétlyukú lemezek behelyezése után a szoros kontroll. Annak ellenére, hogy fiatal betegeknél a mútétet technikailag nehezebb kivitelezni, lehetőleg mégis minél fiatalabb életkorban, az epiphysis megfelelő csontosodásának idején már el kellene végeznünk azt, hogy megelőzzük a kóros növekedést. Egy későbbi életszakaszban a kezelést akár meg is lehet ismételni újabb lemezek behelyezésével. Végül megállapíthatjuk, hogy a 8-as lemezes temporaer epiphyseodesis által elért irányított növekedés segítségével nemcsak idiopathiás, hanem csontdysplasiák és csontanyagcserebetegségek okozta tengelydeformitások is jól kezelhetők, ahol a physisek múködése az alapbetegségből eredően önmagában is érintett. 


\section{IRODALOM}

1. Atar D., Lehman W. B., Grant A. D., Strongwater A.: A simplified method for percutaneous epiphysiodesis. Orthop. Rev. 1990. 19. (4): 358-364.

2. Blount W. P., Clarke G. R.: Control of bone growth by epiphyseal stapling; a preliminary report. J. Bone Joint Surg. Am. 1949. 31-A. (3): 464-478.

3. Boero S., Michelis M. B., Riganti S.: Use of the eight-Plate for angular correction of knee deformities due to idiopathic and pathologic physis: initiating treatment according to etiology. J. Child Orthop. 2011. 5. (3): 209-216.

4. Bowen J. R., Johnson W. J.: Percutaneous epiphysiodesis. Clin. Orthop. Relat. Dis. 1984. 190: 170-173.

5. Burghardt R., Herzenberg J., Standard S., Paley D.: Temporary hemiepiphyseal arrest using a screw and plate device to treat knee and ankle deformities in children: a preliminary report. J. Child Orthop. 2008. 2. (3): 187-197.

6. Burghardt R. D., Herzenberg J. E.: Temporary hemiepiphysiodesis with the eight-Flate jor anguiar dejormities: mia-ierrn results. J. Orthop. Sci. 2010. 15. (5): 699-704.

7. Cho T. J., Choi I. H., Chung C. Y., Yoo W. J., Park M. S., Lee D. Y.: Hemiepiphyseal stapling for angular deformity correction around the knee joint in children with multiple epiphyseal dysplasia. J. Pediatr. Orthop. 2009. 29. (1): 52-56.

8. Ilharreborde B., Gaumetou E., Souchet P., Fitoussi F., Presedo A., Penneçot G. F., Mazda K.: Efficacy and late complications of percutaneous epiphysiodesis with transphyseal screws. J. Bone Joint Surg. Br. 2012. 94-B. (2): 270-275.

9. Metaizeau J. P., Wong-Chung J., Bertrand H., Pasquier P.: Percutaneous epiphysiodesis using transphyseal screws (PETS). J. Pediatr. Orthop. 1998. 18: 363-369.

10. Novais E., Stevens P. M.: Hypophosphatemic rickets: the role of hemiepiphysiodesis. J. Pediatr. Orthop. 2006. 26. (2): 238244.

11. Phemister D. B.: Operative arrestment of longitudinal growth of bones in the treatment of deformities. J. Bone Joint Surg. Am. 1933. 15: 1-15.

12. Sabharwal S., Zhao C., Edgar M.: Lower limb alignment in children: reference values based on a full-length standing radiograph. J. Pediatr. Orthop. 2008. 28. (7): 740-746.

13. Stevens P. M.: Guided growth for angular correction: a preliminary series using a tension band plate. J. Pediatr. Orthop. 2007. 27. (3): 253-259.

14. Stevens P. M., Klatt J. B.: Guided growth for pathological physes: radiographic improvement during realignment. J. Pediatr. Orthop. 2008. 28. (6): 632-639.

\section{Dr. Horváth Nikoletta}

SE ÁOK Ortopédiai Klinika

1113 Budapest, Karolina út 27. 